\title{
Rola autoimmunizacji w rozwoju powikłań cukrzycowych - przegląd badań
}

\author{
Magdalena Łukawska-Tatarczuk ${ }^{1,2}$, Beata Mrozikiewicz-Rakowska², Edward Franek ${ }^{1,3}$, Leszek Czupryniak ${ }^{2}$
}

${ }^{1}$ Klinika Chorób Wewnętrznych, Endokrynologii i Diabetologii, CSK MSWiA, Warszawa

${ }^{2}$ Klinika Diabetologii i Chorób Wewnętrznych, Warszawski Uniwersytet Medyczny

${ }^{3}$ Instytut Medycyny Doświadczalnej i Klinicznej im. M. Mossakowskiego, Polska Akademia Nauk

Abstrakt

Przewlekłe powikłania cukrzycy są główną przyczyną obniżenia jakości życia, niepełnosprawności, a nawet przedwczesnej śmierci pacjentów cierpiących na tę chorobę. Mimo istotnego postępu w dziedzinie farmakoterapii, ich leczenie pozostaje nadal wyzwaniem w codziennej praktyce klinicznej. Brak terapii przyczynowej wynika z niewystarczającego zrozumienia molekularnych mechanizmów uszkadzających poszczególne narządy w cukrzycy. Uważa się, że etiopatogeneza tych powikłań jest złożona i zależy od czynników genetycznych i środowiskowych. W ich rozwoju, oprócz zaburzeń metabolicznych związanych z hiperglikemią, nasilenia stresu oksydacyjnego, dysfunkcji śródbłonka, indukcji stanu zapalnego, coraz częściej wskazuje się też na znaczącą rolę zaburzeń immunologicznych. Wyniki badań doświadczalnych przeprowadzonych na zwierzętach, jak również na hodowlach tkankowych, oraz obserwacje kliniczne potwierdzają udział układu odpornościowego obejmujący aktywność autoreaktywnych limfocytów oraz cytotoksyczne działanie autoprzeciwciał w rozwoju poszczególnych powikłań w obu typach cukrzycy. Wydaje się zatem, że zachwianie równowagi immunologicznej wyzwalające autoagresję jest ważnym czynnikiem przyczyniającym się do dysfunkcji poszczególnych organów w typach cukrzycy 1 i 2.

Dokładne zrozumienie immunopatogenezy tych zaburzeń może zmienić dotychczasowe podejście w leczeniu powikłań cukrzycy oraz umożliwić opracowanie skutecznej terapii przyczynowej ukierunkowanej na układ odpornościowy. Identyfikacja swoistych autoprzeciwciał mogłaby usprawnić ich wczesną diagnostykę i prewencję. W artykule podjęto próbę analizy czynników ryzyka najczęstszych schorzeń o podłożu autoimmunizacyjnym, ich związku z typem 1 i 2 cukrzycy oraz podsumowano potencjalne znaczenie autoagresji w rozwoju jej powikłań w oparciu o wyniki dotychczasowych badań doświadczalnych i klinicznych.

Słowa

kluczowe powikłania cukrzycowe • podłoże autoimmunizacyjne • autoprzeciwciała • schorzenia autoimmunizacyjne

Received: 12.09.2020, Accepted: 17.06.2021

Abstract

Chronic, diabetic complications are the major causes of disability, reduced quality of life and premature deaths of diabetic patients. Despite significant progress in the field of pharmacotherapy, their treatment remains a considerable challenge for health care providers. The lack of causal therapy results from an insufficient understanding of the mechanisms that lead to organ damage in diabetes. It is believed that etiopathogenesis of diabetic complication is multifactorial and complex and depends on the interplay between genetic and environmental factors. In addition to the hyperglycemia-associated alterations, enhanced oxidative stress, endothelial dysfunction, induction of inflammation, recent evidence has pointed out that immunopathogenic mechanisms also play an important role in the development of these complications.

The results from experimental investigations on animals as well as on tissue cultures and clinical observations have demonstrated the involvement of the immune system in the pathogenesis of diabetic complications, which consists in the activity of autoreactive lymphocytes and the cytotoxic effect of autoantibodies. Interestingly, this has been observed not only for type 1 but also for type 2 models of diabetes. Therefore, it seems that the imbalance in the immune system resulting in self-aggression may be an important factor contributing to the dysfunction of individual organs for both types of diabetes.

A more thorough understanding of the immunopathogenesis of these disorders may change the current approach for the treatment of diabetic complications and allow the use of effective, causal therapy targeting the immune mechanisms. Identification of specific autoantibodies could improve the early diagnosis and prevention of diabetic complications. The article presents an analysis of risk factors for the most common autoimmune diseases, their relationship with type 1 and 2 diabetes, and summarizes the potential role of autoimmunity in the development of its complications based on the results of previous experimental and clinical studies.

\section{Keywords}

diabetic complications • autoimmune pathogenesis • autoantibodies • autoimmune disorders 


\section{Wstęp}

Początek XX wieku to dynamiczny okres badań nad układem immunologicznym, a wypracowana wtedy koncepcja "horror autotoxicus" zakładała istnienie mechanizmów chroniących organizm przed autoagresją, których niezawodność miała być krytyczna do przeżycia organizmu [1]. Kolejne lata badań wykazały jednak, że ich dysfunkcja może zaistnieć i doprowadzić do schorzeń autoimmunizacyjnych [2], a samo wytwarzanie autoprzeciwciał pełni ważną rolę w utrzymaniu homeostazy, również w stanie fizjologii [3]. Udowodniono, że obiektem ataku przeciwciał mogą być enzymy, hormony, składniki jądra komórkowego, cytoplazmy lub błon komórkowych. Przełomem w zrozumieniu patogenezy cukrzycy insulinozależnej było odkrycie w 1974 r. specyficznych przeciwciał przeciwko komórkom wysp trzustkowych [4]. Z biegiem lat wyodrębniono różne typy cukrzycy, w zależności od etiologii i przebiegu klinicznego. Zaburzenia autoimmunizacyjne uznano za podstawowe czynniki w podłożu patogenetycznym cukrzycy typu 1 i typu LADA, hiperinsulinizm i insulinooporność, w rozwoju cukrzycy typu 2. W 2001 r. Wilkin zaproponował „hipotezę akceleratora", wedle której u podłoża niewydolności wewnątrzwydzielniczej trzustki są trzy procesy: wrodzone szybkie tempo apoptozy komórek beta, insulinooporność oraz autoimmunizacja [5]. Według tej koncepcji wymienione procesy występują w każdym typie cukrzycy, ujawniając się w stopniu zależnym od czynników genetycznych [6]. Badania następnych lat potwierdziły udział komórek układu odpornościowego w patogenezie otyłości i cukrzycy typu 2, sugerując ważną rolę autoimmunizacji w jej rozwoju [7]. Podejrzewa się, że zaburzenia metaboliczne związane z hiperglikemią z czasem ograniczają prawidłową funkcję układu immunologicznego, przyczyniając się do zwiększenia liczby autoreaktywnych limfocytów oraz uwalniania cytokin prozapalnych, powodując rozwój przewlekłego stanu zapalnego [8]. Badania przeprowadzone na zwierzętach sugerują natomiast, że to zaburzenia autoimmunizacyjne leżą u podłoża insulinooporności, w wyniku wytwarzania

Tabela 1. Charakterystyka najczęstszych schorzeń autoimmunizacyjnych

\begin{tabular}{|c|c|c|c|c|}
\hline $\begin{array}{c}\text { Choroby } \\
\text { autoimmunologiczne }\end{array}$ & Autoantygen & $\begin{array}{c}\text { Przeciwciała wykrywane } \\
\text { w surowicy }\end{array}$ & $\begin{array}{l}\text { Czynniki } \\
\text { genetyczne }\end{array}$ & Czynniki środowiskowe \\
\hline $\begin{array}{l}\text { Autoimmunologiczne za- } \\
\text { palenie tarczycy }\end{array}$ & $\begin{array}{l}\text { - tyreoperoksydaza (TPO) } \\
\text { - tyreoglobulina (ATG) } \\
\text { - receptory dla TSH }\end{array}$ & $\begin{array}{c}\text { - anty-TPO obecne w } 90 \% \text { choroby } \\
\text { Hashimoto i } 75 \% \text { Gravesa-Base- } \\
\text { dowa (ChGB) } \\
\text { - anty-TG w } 60 \% \text { choroby Hashi- } \\
\text { moto i } 30 \% \text { ChGB [14], } \\
\text { - anty-TSHr obecny w ok. } 98 \% \\
\text { ChGB [15] }\end{array}$ & $\begin{array}{c}\text { polimorfizmy w układzie HLA } \\
\text { klasy I, II, DR3, B8 [16], } \\
\text { w genie CTLA-4, PTPN } 22 \\
\text { i wiele innych oraz zaburzenia } \\
\text { epigenetyczne [2] }\end{array}$ & $\begin{array}{l}\text { nadmiar jodu, } \\
\text { niedobór selenu, } \\
\text { leki np. sole litu, } \\
\text { IFN-gamma, } \\
\text { infekcje, } \\
\text { toksyny [17] }\end{array}$ \\
\hline Cukrzyca typu 1 & $\begin{array}{l}\text { - dekarboksylaza kwasu } \\
\text { glutaminowego } \\
\text { - insulina endogenna } \\
\text { - fosfataza tyrozyny } \\
\text { - antygeny komórek } \beta \\
\text { wysp trzustki } \\
\text { - transporter cynku } 8\end{array}$ & $\begin{array}{c}\text { - GADA, } \\
\text { - IAA, } \\
\text { - IA-2, IA2beta, } \\
\text { - ICA, } \\
\text { - ZnT8A, } \\
\text { obecne co najmniej } 4 \text { z nich u 99\% } \\
\text { chorych z cukrzycą typu } 1[18]\end{array}$ & $\begin{array}{c}\text { polimorfizmy w układzie HLA } \\
\text { klasy I, II, DQ2, DQ8, PTPN- } \\
\text { 22, region genu insuliny [19] } \\
\text { oraz zaburzenia epigenetyczne } \\
{[20]}\end{array}$ & $\begin{array}{c}\text { zakażenia wirusowe, } \\
\text { dieta, toksyny (pochodne } \\
\text { N-nitrozowe), } \\
\text { stres, warunki klimatyczne } \\
{[21]}\end{array}$ \\
\hline Choroba Addisona & $\begin{array}{l}\text { - 21-hydroksylaza } \\
\text { - 17a-hydroksylaza, } \\
\text { - P450scc (enzym } \\
\text { oddzielający łańcuch } \\
\text { cholesterolu) }\end{array}$ & $\begin{array}{l}\text { - przeciwko } 21 \text {-hydroksylazie } \\
\text { obecne u ok. } 86 \% \text { chorych [22] }\end{array}$ & $\begin{array}{l}\text { HLA DR3-DQ2/ DR4-DQ8 [22], } \\
\text { geny UGT2B28 i ADAM3A [23], } \\
\text { metylacja DNA [24]. }\end{array}$ & $\begin{array}{l}\text { zakażenia wirusowe [25], } \\
\text { stres, leki np. IFN I i III [26]. }\end{array}$ \\
\hline Niedokrwistość złośliwa & $\begin{array}{l}\text { - komórki okładzinowe } \\
\text { żołądka } \\
\text { - czynnik wewnętrzny }\end{array}$ & $\begin{array}{c}\text { - przeciwko komórkom } \\
\text { okładzinowym żołądka (APCA) u ok. } \\
90 \% \text { chorych } \\
\text { - przeciwko czynnikowi } \\
\text { wewnętrznemu (IF) u ok. } 60 \% \\
\text { chorych [27] }\end{array}$ & $\begin{array}{c}\text { polimorfizm pojedynczego } \\
\text { nukleotydu rs9606756 genu } \\
\text { transkobalaminy } 2 \text { TCN2 [28] }\end{array}$ & zakażenie H. pylori [29] \\
\hline Celiakia & $\begin{array}{l}\text { - transglutaminaza } \\
\text { tkankowa (tTG) }\end{array}$ & $\begin{array}{c}\text { - przeciwko tkankowej transgluta- } \\
\text { minazie tTGAb [30], endomysium } \\
\text { EmA i gliadynie AGA obserwowane } \\
\text { u > }>90 \% \text { chorych [11] }\end{array}$ & $\begin{array}{c}\text { warianty genów HLA-DQ2, } \\
\text { HLA-DQ8 [31] oraz poli- } \\
\text { morfizmy ponad } 40 \text { genów } \\
\text { związanych z układem immu- } \\
\text { nologicznym [32] }\end{array}$ & $\begin{array}{l}\text { dieta, zaburzenie flory } \\
\text { jelitowej [33] }\end{array}$ \\
\hline
\end{tabular}

Na podstawie $[2,11,14,15,16,17,18,19,20,21,22,23,24,25,26,27,28,29,30,31,32,33,34,35,36]$. 
patogennych autoprzeciwciał IgG przez limfocyty B [9] oraz dysfunkcję limfocytów T CD4+ w trzewnej tkance tłuszczowej [10]. Wydaje się więc, że tak jak złożona jest patogeneza obu typów cukrzycy, tak i wieloczynnikowa jest etiologia jej powikłań. Dane z piśmiennictwa sugerują, że u ich podstaw leżą złożone, wzajemnie powiązane mechanizmy patofizjologiczne wywołane przez zaburzenia metaboliczne związane z hiperglikemią, indukcją stanu zapalnego oraz autoimmunizacją. Wynikają najprawdopodobniej z interakcji między predysponującymi genami a czynnikami środowiskowymi. Identyfikacja komponenty immunologicznej może nie tylko uzupełnić brakującą wiedzę, ale również stworzyć nowe możliwości terapeutyczne. W artykule przedstawiono analizę czynników ryzyka najczęstszych schorzeń autoimmunizacyjnych, ich związek z typem 1 i 2 cukrzycy oraz potencjalną rolę autoagresji w rozwoju powikłań cukrzycowych.

\section{Epidemiologia i czynniki ryzyka rozwoju chorób autoimmunizacyjnych}

Według danych epidemiologicznych schorzenia autoimmunizacyjne dotyczą prawie $9 \%$ populacji, częściej występują u kobiet niż u mężczyzn [11]. Wzrost zachorowalności $z$ ich powodu obserwowany szczególnie w krajach uprzemysłowionych wskazuje na ważny udział czynników środowiskowych, do których zalicza się: warunki klimatyczne, zanieczyszczenie powietrza, status społecznoekonomiczny, czynniki zakaźne, palenie tytoniu, stres, dietę oraz skład mikroflory jelitowej [12]. Ponadto podejrzewa się, że czynniki środowiskowe wpływają na ekspresję genów przez mechanizmy epigenetyczne, które mogą się przyczyniać do rozwoju wielu chorób autoimmunizacyjnych [13]. Przykłady najczęstszych schorzeń autoimmunizacyjnych, znane autoantygeny, przeciwciała oraz najlepiej poznane czynniki genetyczne i środowiskowe uczestniczące $w$ ich patogenezie przedstawiono w tabeli 1.

Podobieństwo czynników genetycznych i środowiskowych w rozwoju poszczególnych schorzeń zdaje się więc częściowo wyjaśniać, dlaczego obecność jednej choroby autoimmunizacyjnej zwiększa ryzyko rozwoju innej. Niemniej jednak pełne zrozumienie immunopatogenezy uszkodzenia narządów w danych zespołach chorobowych wciąż pozostaje obiektem badań.

\section{Związek cukrzycy typu $1 \mathrm{z}$ rozwojem innych chorób autoimmunizacyjnych}

Jedną $z$ najczęstszych chorób autoimmunizacyjnych, związaną z występowaniem wielu powikłań, jest cukrzyca typu
1. Według metaanalizy opublikowanej w 2019 r. i obejmującej około 294 tys. pacjentów z cukrzycą typu 1, najczęstszymi chorobami autoimmunizacyjnymi współwystępującymi z nią są: autoimmunizacyjne choroby tarczycy $(9,8 \%)$, celiakia $(4,5 \%)$, autoimmunologiczne zapalenie błony śluzowej żołądka (4,3\%), bielactwo $(2,4 \%)$, choroba Addisona $(0,2 \%)$ [37]. Wykazano, że za predyspozycję genetyczną do rozwoju kolejnej choroby autoimmunizacyjnej, oprócz cukrzycy typu 1, może odpowiadać polimorfizm genu PTPN22 oraz genotyp HLA DRB1*0405-DQB1*0401 [38]. Podejrzewa się, że spośród czynników środowiskowych patogenną rolę odgrywają: zakażenia wirusowe (zwłaszcza wywołane enterowirusami) [39], zaburzenie mikroflory jelitowej [40], silny stres [41], wzrost poziomu higieny społeczeństwa powodujący obniżenie liczby infekcji hipotetycznie mogących korzystnie stymulować odporność [42]. Ochronną rolę może pełnić karmienie piersią [43], suplementacja witaminy D [44] oraz spożywanie wielonienasyconych kwasów tłuszczowych omega-3 [45].

\section{Związek cukrzycy typu 2 z chorobami autoimmunizacyjnymi}

Najnowsze hipotezy badawcze zakładają, że cukrzyca typu 2, podobnie jak cukrzyca typu 1, może należeć do schorzeń autoimmunizacyjnych. Wiedza na temat współwystępowania cukrzycy typu 2 z innymi chorobami autoimmunizacyjnymi jest jednak ograniczona. Analizując dane 757368 pacjentów z populacji szwedzkiej wykazano zarówno wyraźnie zwiększone ryzyko rozwoju cukrzycy typu 2 u pacjentów z chorobami autoimmunizacyjnymi, jak i większe ryzyko chorób autoimmunizacyjnych u chorych $z$ cukrzyca typu 2 [46]. Przewlekłe limfocytarne zapalenie tarczycy jest najprawdopodobniej chorobą autoimmunizacyjną najczęściej współwystępującą z cukrzycą typu 2, zwłaszcza u chorych $z$ dodatnim wywiadem rodzinnym $w$ kierunku chorób tarczycy [19]. Udowodniono, że w populacji osób w podeszłym wieku z cukrzycą typu 2 występuje 2,5-krotnie większe prawdopodobieństwo wystąpienia autoimmunizacji tarczycy w porównaniu do osób bez cukrzycy. Można wprawdzie podejrzewać, iż może to zależeć od niedoboru witaminy $D$, ale nie wykazano związku przyczynowego [47]. Natomiast wyniki innych badań sugerują, że wśród pacjentów z cukrzycą typu 2 źle wyrównaną, mimo leczenia insuliną, ryzyko rozwoju celiakii jest nieco wyższe niż w populacji ogólnej [48]. Wydaje się zatem, że komponent autoimmunizacyjny prowadzący do niewydolności wewnątrzwydzielniczej trzustki w cukrzycy typu 2 może mieć związek ze zwiększeniem ryzyka rozwoju innych chorób autoimmunizacyjnych. Udowodniono, że już w insulinooporności i otyłości obserwuje się zaburzoną - wrodzoną i nabytą - odpowiedź immunologiczną 
stymulującą rozwój przewlekłego stanu zapalnego o niskim stopniu nasilenia [7]. W jednym z badań wykazano, że chorzy z cukrzycą typu 2 powikłaną retinopatią cukrzycową w porównaniu do chorych bez powikłań mają w surowicy wyższe stężenia cytokin prozapalnych, tj. TNF-alfa i IL-2 wydzielanych przez limfocyty Th1, a niższe stężenia cytokin działających przeciwzapalnie, tj. IL-4 i -10 - wydzielanych przez limfocyty Th2 [49]. Coraz więcej wyników badań sugeruje udział układu odpornościowego w patogenezie cukrzycy typu 2 oraz jej powikłań, wskazując na możliwość zastosowania nowych immunoterapii ukierunkowanych na redukcję stanu zapalnego [50]. W jednym z badań podano, iż metformina - lek powszechnie stosowany w cukrzycy typu 2 - nie tylko obniża glikemię, ale również zmniejsza nasilenie stanu zapalnego przez zmniejszenie liczby makrofagów typu 1, na korzyść makrofagów typu 2 wydzielających IL-4 i -10 [51] oraz ogranicza aktywność szlaku NF-kB i wytwarzanie IL-1 $\beta$ [52]. Od czasu publikacji wyników badania CANTOS (Canakinumab Anti-inflammatory Thrombosis Outcomes Study) nową perspektywą terapeutyczną stało się farmakologiczne zablokowanie IL-1 $\beta$ w powikłaniach sercowo-naczyniowych [53]. W dużym randomizowanym prospektywnym badaniu CANTOS wykazano, że terapia kanakinumabem, czyli przeciwciałem monoklonalnym neutralizującym działanie IL-1ß, zmniejszyła ryzyko częstości nawracających zdarzeń sercowo-naczyniowych w porównaniu z placebo, niezależnie od obniżenia stężenia lipidów [54]. Brak danych o długoterminowym bezpieczeństwie stosowania leków biologicznych nadal ogranicza możliwości wykorzystania nowych immunoterapii. Uwzględniając wzrost ryzyka rozwoju cukrzycy typu 2 po zastosowaniu leków immunosupresyjnych, wynikający z nasilenia zaburzeń metabolicznych, wydaje się, że sama autoimmunizacja choć obecna w jej patogenezie, odgrywa zasadniczo mniejszą rolę niż w cukrzycy typu 1.

\section{Mechanizmy utrzymujące tolerancję na własne autoantygeny a powikłania cukrzycowe}

Jednym z głównych zadań układu odpornościowego jest utrzymanie tolerancji na własne antygeny, a mechanizmy, które za to odpowiadają, można podzielić na centralne i obwodowe. Zaburzenie tych procesów mogą spowodować zarówno czynniki endogenne, jak i egzogenne (ryc. 1). W procesie dojrzewania limfocytów podstawowe znaczenie mają znajdujące się na nich receptory błonowe oraz ich zdolność do rozpoznawania cząsteczek głównego kompleksu zgodności tkankowej (MHC). Jeżeli limfocyty słabo wiążą MHC, ulegają selekcji pozytywnej, czyli tej umożliwiającej przeżycie. Natomiast w przypadku silnego wiązania przez limfocyty MHC - podlegają selekcji negatywnej, czyli apoptozie [55]. Nawet jeżeli w grasicy lub szpiku kostnym zawiodą centralne mechanizmy eliminacji autoreaktywnych limfocytów, to ich eliminacja powinna nastąpić w narządach obwodowych. Do mechanizmów obwodowych zabezpieczających przed aktywnością autoreaktywnych limfocytów zalicza się:

- $\quad$ sekwestrację antygenu, czyli oddzielenie go od limfocytów barierą anatomiczną;

- delecję klonalną, czyli apoptozę autoreaktywnych limfocytów;

- $\quad$ anergię klonalną, tj. wprowadzenie ich w stan „uśpienia” oraz

- $\quad$ aktywną supresję z udziałem limfocytów pomocniczych [48].

Najlepiej poznanymi komórkami układu odpornościowego uczestniczącymi w destrukcji komórek beta wysp trzustki są autoreaktywne limfocyty $T$ cytotoksyczne oraz swoiste przeciwciała wydzielane przez autoreaktywne limfocyty B. W zaburzeniach autoimmunizacyjnych u chorych z cukrzycą prawdopodobnie równie ważną rolę odgrywają inne grupy komórek, które uczestniczą w utrzymaniu mechanizmów tolerancji na własne antygeny.

Jedną z subpopulacji limfocytów pomocniczych są limfocyty regulatorowe (Treg) CD4+CD25+ uważane za główne w utrzymywaniu równowagi immunologicznej. Mutacja w swoistym dla nich czynniku transkrypcyjnym Foxp3 jest związana z rozwojem wielu chorób autoimmunizacyjnych [58]. Mniejszą liczbę limfocytów Treg obserwowano zarówno w cukrzycy typu 1 [59], jak i 2 [60]. Istotne, że zachwianie proporcji w subpopulacjach poszczególnych limfocytów korelowało z rozwojem powikłań cukrzycowych. Wykazano zmniejszenie liczby limfocytów Treg u chorych z cukrzycą typu 1 oraz powikłaniami sercowo-naczyniowymi, w porównaniu do chorych bez powikłań [61]. W cukrzycy typu 2 zaobserwowano natomiast zależność między mniejszą liczbą limfocytów Treg a obecnością nefropatii cukrzycowej [62]. Obecność tego powikłania wiązała się również z większą liczbą limfocytów T pomocniczych typu 17 (Th17) [62], które wydzielają IL-17, sprzyjającą indukcji autoimmunizacyjnego zapalenia tkanek [63]. Uważa się, że Th17 odpowiadają za rozwój przewlekłego stanu zapalnego w obu typach cukrzycy [64]. W niedawnych doniesieniach wskazuje się możliwość wykorzystania przeciwciała monoklonalnego przeciwko Th17, jako potencjalną opcję terapeutyczną w retinopatii [65] i nefropatii cukrzycowej [66] oraz w zahamowaniu schyłkowej niewydolności nerek u chorych z cukrzycą [67].

Inną grupą komórek kontrolujących funkcje układu odpornościowego przez uczestnictwo w centralnych i obwodowych mechanizmach tolerancji są komórki dendrytyczne [66]. Jako komórki prezentujące antygen odgrywają ważną rolę w ograniczeniu nadmiernej aktywności limfocytów T, B lub makrofagów. Jak wykazano odpowiadają za to łącznie z receptorami, takimi jak CTLA-4 oraz PD-1 ulegającymi wzmożonej ekspresji na aktywowanych 
komórkach układu odpornościowego. Udowodniono, że zahamowanie tych receptorów przez przeciwciała monoklonalne zwiększa ryzyko rozwoju cukrzycy typu 1 [68]. Na podstawie badań doświadczalnych - wymagających jednak potwierdzenia w badaniach klinicznych - niedojrzałe komórki dendrytyczne łącznie z limfocytami Treg mogłyby na wczesnym etapie zatrzymać proces autoimmunizacyjny i rozwój cukrzycy insulinozależnej [21]. Dysfunkcję komórek dendrytycznych wiąże się również z uszkodzeniem śródbłonka [69] oraz stanem zapalnym niskiego stopnia tkanki tłuszczowej u chorych z cukrzycą typu 2 [70].

Komórkami uznawanymi za „pomost” między odpowiedzią wrodzoną i nabytą w zachowaniu tolerancji na autoantygeny są komórki NK [56]. Uczestniczą w powstawaniu „komórek pamięci”, przez wydzielanie IFN-y mogą się przyczyniać do nadmiernejiniekontrolowanejodpowiedziautoimmunizacyjnej, w której pośredniczą autoreaktywne komórki T. Zachwianie równowagi między różnymi podgrupami komórek NK obserwowano w zaostrzeniu cukrzycy insulinozależnej [71]. Dysfunkcja komórek NK opisywana była również u kobiet w ciąży i jest powiązana z rozwojem insulinooporności i otyłości $[72,73]$.

Stwierdzany wzrost ryzyka rozwoju powikłań cukrzycowych wraz z wiekiem oraz czasem trwania cukrzycy może również tłumaczyć zjawisko immunosenescencji, czyli starzenia się układu odpornościowego, którego następstwem jest stały, przewlekły stan zapalny [8, 74].

\section{Autoprzeciwciała jako markery powikłań cukrzycowych}

Identyfikacja autoprzeciwciał i wykazanie ich związku z poszczególnymi chorobami stało się pomocne w diagnostyce, inicjując podział schorzeń autoimmunizacyjnych w zależności od umiejscowienia na narządowoswoiste, np. cukrzyca typu 1 oraz nieswoiste, takie jak np. toczeń rumieniowaty układowy [75]. Ten podział wydaje się jednak niedoskonały, jeżeli uwzględni się zakres obserwowanych objawów, które wykraczają poza jeden narząd - nawet w chorobach, w których wykrywa się przeciwciała swoiste narządowo, np. w cukrzycy typu 1. Wiedza na temat obecności autoprzeciwciał i ich znaczenia w progresji powikłań cukrzycowych nadal jest ograniczona (tabela 2). Wykorzystanie ich jako markerów diagnostycznych umożliwiłoby identyfikację chorych najbardziej zagrożonych rozwojem poszczególnych powikłań cukrzycowych oraz wczesną prewencję, dlatego są przedmiotem wielu badań, które przedstawiono niżej.

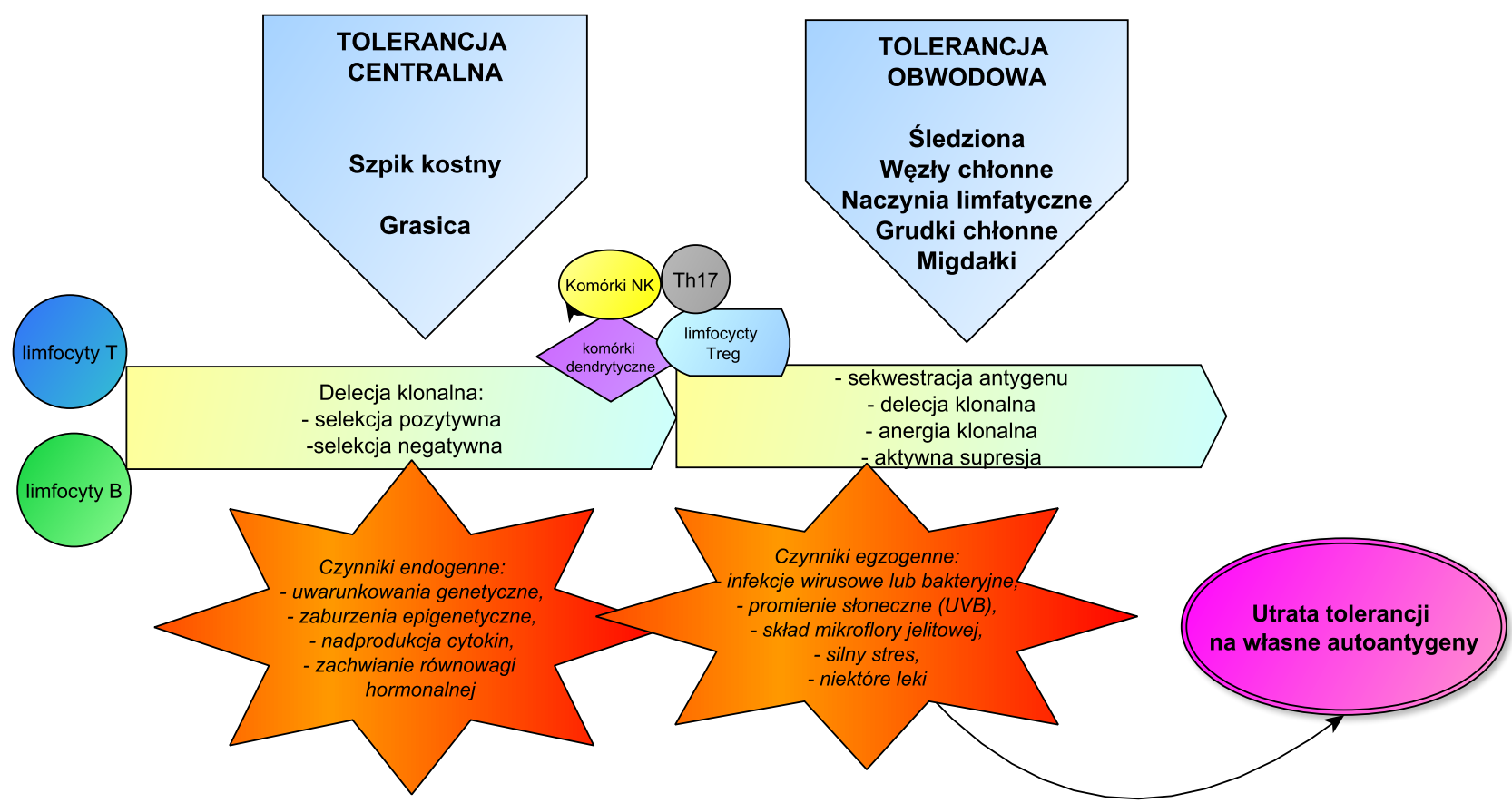

Rycina 1. Mechanizmy tolerancji centralnej i obwodowej, podzbiory komórek układu odpornościowego zaangażowane w ich regulację (szczegóły w tekście) oraz główne czynniki zaburzające ich funkcjonowanie, wg [54, 56, 57] 


\section{Autoprzeciwciała w retinopatii cukrzycowej}

W retinopatii cukrzycowej jednym z pierwszych autoantygenów podejrzewanych o wywoływanie reakcji autoimmunizacyjnej były perycyty, czyli multipotencjane komórki pełniące ważną rolę w prawidłowym funkcjonowaniu naczyń krwionośnych siatkówki. Obecność przeciwciał przeciwko nim wykazano, co istotne, również u chorych w stanie przedcukrzycowym z tendencją obniżania się ich miana w miarę wzrostu stopnia zaawansowania retinopatii [77]. Potwierdzono również bardzo częste występowanie autoprzeciwciał przeciwko perycytom u chorych z nieproliferacyjną postacią retinopatii cukrzycowej ( $55 \%)$, a zmniejszenie ich miana w miarę rozwoju choroby powiązano $z$ utratą perycytów [78]. W innym badaniu dowiedziono natomiast nie tylko wyższe stężenie przeciwciał przeciwko perycytom u chorych z cukrzycą typu 2 i retinopatią, w porównaniu do grupy kontrolnej, ale również wykazano związek z większą aktywnością komórek dopełniacza (C3a i C5a) [79]. W badaniach przeprowadzonych w niewielkich grupach chorych wykazano obecność innych autoprzeciwciał, które prawdopodobnie uczestniczą w destrukcji narządu wzroku u chorych z cukrzycą. Były to:
- $\quad$ przeciwciała przeciwko utlenionej postaci lipoprotein o małej gęstości, obserwowane częściej u chorych z cukrzycą typu 2, powikłaną retinopatią proliferacyjną i najprawdopodobniej powiązane ze stanem zapalnym $[80,81]$;

- przeciwciała przeciwko anhydrazie węglanowej II, korelujące $\mathrm{z}$ występowaniem retinopatii $\mathrm{u}$ chorych z cukrzycą typu 1 [84];

- $\quad$ przeciwciała przeciwko mieloperoksydazie i kolagenowi II, korelujące z zaostrzeniem retinopatii [82, 85];

- przeciwciała przeciwko heksokinazie 1 i fumarazie obserwowane częściej u chorych z cukrzycowym obrzękiem plamki żółtej [18, 83].

\section{Autoprzeciwciała w nefropatii cukrzycowej}

Powikłaniem cukrzycowym, w którego rozwoju najprawdopodobniej biorą udział czynniki immunologiczne, jest nefropatia cukrzycowa. W badaniu przeprowadzonym na modelu zwierzęcym cukrzycy typu 1 (u nieotyłych myszy z cukrzycą, NOD - non-obese diabetic mice), wykazano udział zarówno komórkowej, jak i humoralnej odpowiedzi

Tabela 2. Podejrzewane autoantygeny będące obiektem autoagresji w patogenezie wymienionych powikłań cukrzycy

\begin{tabular}{|c|c|c|}
\hline Nazwa powikłania & Autoantygeny & Piśmiennictwo \\
\hline Mikroangiopatie & kolagen typu IV & [76] \\
\hline \multirow[t]{7}{*}{ Retinopatia } & perycyty & {$[77,78,79]$} \\
\hline & oxLDL & {$[80,81]$} \\
\hline & MPO & [82] \\
\hline & heksokinaza 1 & [18] \\
\hline & fumaraza & [83] \\
\hline & anhydraza węglanowa II & [84] \\
\hline & kolagen typu II & [85] \\
\hline \multirow[t]{2}{*}{ Nefropatia } & oxLDL & {$[86,87]$} \\
\hline & komórki śródbłonka & [88] \\
\hline Neuropatia obwodowa & gangliozydy & {$[89,90]$} \\
\hline Neuropatia autonomiczna & komórki zwoju współczulnego rdzenia nadnerczy & {$[91]$} \\
\hline Niewydolność serca w cukrzycy & a-MyHC, vimentyna, $\mathrm{K}$ alpha 1 -tubulina, troponina, aktynina 2 & {$[92,93]$} \\
\hline Gastropareza & GnRH1, progonadoliberyna-2, LH & {$[33,94]$} \\
\hline Neuroartropatia & oksydacyjnie zmodyfikowany kolagen typu II & [95] \\
\hline
\end{tabular}


immunologicznej, już we wczesnych stadiach rozwoju tego powikłania. Wykryto m.in. obecność autoprzeciwciał skierowanych przeciwko składnikom kłębuszków nerkowych, których nie było u myszy bez cukrzycy. Obserwowane zmiany immunologiczne występujące pod postacią złogów lgG i komórek dopełniacza C3 korelowały ze wzrostem albuminurii i rozwojem niewydolności nerek [96]. Podobne wyniki uzyskano w badaniu pilotażowym przeprowadzonym u dzieci z cukrzycą typu 1, w którym wykazano obecność krążących kompleksów immunologicznych, złożonych z autoprzeciwciał IgG, które najprawdopodobniej były przyczyną rozwoju nefropatii [97]. Innym z autoantygenów podejrzewanych o udział w rozwoju powikłań nerkowych u chorych z cukrzycą są zmodyfikowane cząsteczki lipidów, znane z właściwości prozapalnych. W badaniu przeprowadzonym wśród niewielkiej grupy chorych z cukrzycą typu 1 wykazano obecność autoprzeciwciał przeciwko zmodyfikowanym cząsteczkom lipoprotein, których liczba korelowała ze stopniem uszkodzenia nerek [87]. Podobne wyniki badań uzyskano oceniając 905 chorych z cukrzycą typu 2, u których obecność przeciwciał IgG reagujących ze zmodyfikowanymi formami lipoprotein tworzyła krążące kompleksy immunologiczne, korelujące z obecnością albuminurii [86]. W jednym z niedawnych badań wykazano ponadto obecność podwyższonego miana przeciwciał przeciwko kolagenowi IV u chorych z cukrzycą insulinoniezależną i nadciśnieniem tętniczym, których liczba korelowała z obecnością powikłań o charakterze mikroangiopatii [76]. Autoantygenem podejrzewanym o udział w patogenezie nefropatii cukrzycowej są komórki śródbłonka. W badaniu VA NEPHRON-D obejmującym 305 chorych z cukrzycą typu 2, obecność przeciwciał przeciwko komórkom śródbłonka miała związek ze stopniem albuminurii, rozwojem schyłkowej niewydolności nerek oraz ze śmiercią z przyczyn nerkowych [88]. Na podstawie tych badań wysunięto podejrzenie, iż odpowiada za to zmniejszona liczba regulatorowych limfocytów $B$, o fenotypie CD19+CD24hiCD38hi obserwowana u chorych z nefropatią cukrzycową [98]. Jak wykazano w innym badaniu, aktywność nefropatii u chorych z cukrzycą korelowała również z większą liczbą limfocytów folikularnych CD4+CXCR5+ oraz stężeniem IL-6 i -17 [99], o właściwościach prozapalnych.

\section{Autoprzeciwciała w neuropatii cukrzycowej}

Neuropatia cukrzycowa jest najczęstszym, przewlekłym powikłaniem cukrzycy o złożonej i wciąż niewystarczająco poznanej etiologii. Oprócz teorii metabolicznej i naczyniowej wyjaśniających jej patogenezę [100], coraz więcej badań wskazuje na udział czynników immunologicznych. $W$ badaniach $z$ ostatnich lat zwracano uwagę na rolę receptorów Toll-podobnych (TLR), które odpowiadają za prawidłowe odróżnienie antygenów „własnych” od „obcych” oraz regulują odpowiedź immunologiczną. Sugeruje się, że sygnalizacja związana z receptorem TLR 2 i 4 wpływa na rozwój neuropatii czuciowej związanej z zaburzeniami metabolicznymi [101]. Wykazano również istotnie wyższe miano przeciwciał przeciwjądrowych ANA w surowicy krwi pacjentów z obwodową neuropatią cukrzycową w porównaniu do grupy kontrolnej [102]. Zauważono też zależność między mianem przeciwciał przeciwgangliozydowych w surowicy chorych z cukrzycą i obwodową neuropatią czuciową a stężeniem białka ostrej fazy (CRP), czynnika wzrostu nowotworów (TNF-alfa) oraz inhibitora aktywatora plazminogenu (PAl-1) [89], co wskazywałoby na ścisłą zależność między procesami autoimmunizacyjnymi i indukcją stanu zapalnego.

Mimo że obecność autoprzeciwciał badana jest od wielu lat, ich rola nadal nie jest dokładnie poznana, a wyniki badań często są sprzeczne. W badaniu 394 pacjentów z cukrzycą typu 1 wskazano częstsze występowanie autoprzeciwciał przeciwko strukturom układu autonomicznego w porównaniu do zdrowych osobników, bez związku z rozwojem retinopatii, nefropatii lub neuropatii obwodowej [91]. Natomiast w badaniu prospektywnym, przeprowadzonym w grupie 112 pacjentów z cukrzycą typu 1 w czasie 16-letniej obserwacji, wykazano związek między obecnością przeciwciał przeciwko strukturom autonomicznego układu nerwowego a ryzykiem rozwoju neuropatii układu autonomicznego. Nieobecność przeciwciał prawie w $90 \%$ wiązała się z prawidłowymi wynikami testów oceniających układ autonomiczny, takich jak próba Valsalvy lub test głębokich oddechów [103]. Związku między wymienionymi przeciwciałami a dysfunkcją układu autonomicznego nie wykazano w grupie chorych z cukrzycą typu 2 [104], co sugerowałoby odmienne podłoże patogenetyczne rozwoju neuropatii w obu typach cukrzycy.

\section{Autoprzeciwciała w niewydolności serca w cukrzycy}

Coraz więcej badań wskazuje, że podłoże patogenetyczne kardiomiopatii cukrzycowej jest złożone i różni się w zależności od typu cukrzycy, przy czym w cukrzycy typu 1 znaczącą rolę w jej rozwoju może odgrywać autoimmunizacja [105]. Proponowanym autoantygenem komórek T CD 4+ w rozwoju kardiomiopatii cukrzycowej jest izoforma a łańcucha ciężkiego miozyny (a-MyHC). Dowiedziono, że zarówno w mysim modelu spontanicznego zapalenia mięśnia sercowego, jak i u ludzi z zapaleniem mięśnia sercowego, w śródszpikowych komórkach nabłonkowych grasicy (mTEC) i obwodowych limfoidalnych komórkach zrębu brakuje transkryptów genów kodujacych $\alpha-\mathrm{MyHC}$, dlatego naruszona zostaje centralna tolerancja wobec tego autoantygenu [106]. Wykazano, że 
w zwierzęcym modelu cukrzycy typu 1 u nieotyłej myszy (NOD) po zawale serca wystąpiło przedłużone wytwarzanie autoprzeciwciał przeciwko a-miozynie sercowej, które nie występowało $w$ modelu myszy bez genetycznej predyspozycji do rozwoju cukrzycy typu 1 (C57BL/6). Co istotne, wytwarzanie autoprzeciwciał korelowało z naciekiem limfocytarnym i destrukcją mięśnia sercowego, wywołując rozwój niewydolności serca [92]. Podobne wyniki uzyskano u chorych z cukrzycą typu 1 po zawale serca, u których prawie u $83 \%$ badanych stwierdzono obecność autoprzeciwciał przeciwko $\alpha$ - i $\beta$-miozynie sercowej, troponinie sercowej lub aktyninie-2, w zestawieniu $z$ chorymi po zawale mięśnia sercowego, bez cukrzycy (przeciwciała były obecne tylko u $4 \%$ badanych) lub z cukrzyca typu 2 (przeciwciała były obecne u $15 \%$ badanych) [92]. W innym badaniu zasugerowano, iż czynnikiem wyzwalającym wytwarzanie przeciwciał przeciwsercowych u chorych na cukrzycę typu 1 może być incydent kwasicy ketonowej. Wyniki tych badań wskazywały na związek między obserwowaną w surowicy chorych po incydencie kwasicy ketonowej obecnością przeciwciał przeciwko miozynie sercowej, vimentynie i K alpha 1-tubulinie, a wytwarzaniem cytokin prozapalnych prowadzących do rozwoju kardiomiopatii cukrzycowej [93]. W badaniu kohortowym potwierdzono związek między obecnością przeciwciał przeciwsercowych, a stanem zapalnym i podwyższonym ryzykiem sercowo-naczyniowym, przy czym zależność ta była istotniejsza u pacjentów ze złym wyrównaniem metabolicznym i występowała tylko $w$ typie 1 cukrzycy [107]. Powyższe obserwacje mogą wyjaśnić gorszy przebieg i rokowanie incydentów sercowo-naczyniowych u pacjentów z cukrzycą typu 1, wskazując na ważny udział dysfunkcji w układzie immunologicznym.

\section{Autoprzeciwciała w enteropatii cukrzycowej}

Według najnowszej hipotezy u podłoża enteropatii cukrzycowej leży nie tylko neuropatia autonomiczna, ale również zaburzenie równowagi między stężeniem insulinopodobnego czynnika wzrostu (IGF-1), a białkiem wiążącym insulinopodobny czynnik wzrostu (IGFBP-3). Podejrzewa się, że obniżenie stężenia IGF-1 w surowicy chorych z cukrzycą typu 1 , przy wzroście stężenia IGFBP-3, wpływa na aktywność receptora TMEM219, znajdującego się w kryptach jelitowych, uruchamiając szlak kaspaz zaburzających różnicowanie komórek macierzystych okrężnicy [108, 109]. Brak negatywnego wpływu IGF-I na wydzielanie hormonu wzrostu powoduje jego nadmierne wydzielanie oraz może wpływać na rozwój powikłań naczyniowych [110]. Najnowsze doniesienia sugerują ponadto związek między równowagą hormonalną a autoimmunizacją w rozwoju enteropatii cukrzycowej. Hormon uwalniający gonadotropinę (GnRH1) coraz częściej postrzegany jest jako główny neuroprzekaźnik w jelitowym układzie nerwowym, a przeciwciała przeciwko niemu mogą mieć związek z przewlekłymi zaburzeniami żołądkowojelitowymi u chorych z cukrzycą [33]. Wykazano wyższe miano przeciwciał przeciwko GnRH1, progonadoliberynie-2, hormonowi luteinizującemu (LH) u chorych z cukrzycą i zaburzeniami żołądkowo-jelitowymi w porównaniu do grupy kontrolnej [94]. Badanie przeprowadzono jednak w niewielkiej grupie chorych, dlatego do określenia dokładnej roli tych autoprzeciwciał w patogenezie powikłań cukrzycowych oraz wykorzystania tej wiedzy w praktyce potrzeba jeszcze wielu badań.

\section{Autoprzeciwciała w rozwoju stawu Charcota}

Powikłaniem cukrzycowym silnie związanym z neuropatią, którego podłoże wciąż pozostaje nie w pełni poznane, jest neuroartropatia Charcota. W jednym $z$ badań obejmującym 124 chorych z cukrzycą typu 2 wykryto obecność przeciwciał przeciwko oksydacyjnie zmodyfikowanemu kolagenowi typu II u chorych z neuroartropatią, co sugerowałoby udział czynników autoimmunizacyjnych $w$ jej patogenezie [95]. Biorąc pod uwagę przebieg i ciężkość tego powikłania oraz brak skutecznej przyczynowej terapii, wydaje się, że pogłębienie wiedzy o immunopatogenezie tego powikłania mogłoby zostać wykorzystane w opracowaniu terapii, która umożliwiłaby skuteczne zahamowanie destrukcji aparatu kostno-stawowego u chorych z cukrzycą.

\section{Podsumowanie}

Najnowsze doniesienia badawcze sugerujące ważny udział układu odpornościowego $w$ rozwoju nie tylko typu 1, ale również typu 2 cukrzycy oraz obserwowany ich związek z innymi schorzeniami o podłożu autoimmunizacyjnym zmieniają sposób postrzegania patogenezy powikłań cukrzycowych. $\mathrm{Na}$ podstawie przeglądu badań można stwierdzić, że komponenta autoimmunizacyjna powodująca ich rozwój, choć obecna w obu typach cukrzycy, bardziej wyrażona jest w cukrzycy insulinozależnej, szczególnie w powikłaniach sercowo-naczyniowych, negatywnie rzutując na przebieg choroby. Tym samym konieczne wydaje się odmienne podejście terapeutyczne do tych powikłań, w zależności od dysfunkcji w układzie immunologicznym pacjenta. Jak wykazano, opisane wyniki wskazujące na udział autoagresji w uszkodzeniu poszczególnych narządów w cukrzycy - choć mają charakter eksperymentalny i dotyczą modeli zwierzęcych - mogą zainspirować badania kliniczne i być może wypracować nowe standardy leczenia powikłań 
cukrzycy z wykorzystaniem terapii ukierunkowanych na układ odpornościowy.

\section{Wykaz skrótów}

ANA - przeciwciała przeciwjądrowe (anti-nuclear antibodies), APCA - autoprzeciwciała przeciwko komórkom okładzinowym żołądka (anti-parietal cell antibody), CTLA4 - antygen 4 limfocytów T cytotoksycznych (cytotoxic T cell antigen 4), FOXP3 - czynnik transkrypcyjny FOXP3 (forkhead box P3), GADA - przeciwciała przeciwko dekarboksylazie kwasu glutaminowego (anti-glutamic acid decarboxylase antibody), GnRH1 - hormon uwalniający gonadotropinę (gonadotropin-releasing hormone), HLA - antygeny ludzkich leukocytów (human leukocyte antigen), IAA - przeciwciała przeciwinsulinowe (insulin autoantibodies), IA2 - przeciwciała przeciw fosfatazie tyrozyny (insulinoma-associated antigen 2), ICA - przeciwciała przeciwwyspowe (islet cell antibodies), IF - czynnik wewnętrzny (intrinsic factor), IFN - interferon, IGF-1 - insulinopodobny czynnik wzrostu (insulin-like growth factor), IGFBP3 - białko wiążące insulinopodobny czynnik wzrostu (insulin-like growth factor-binding protein 3), IL interleukina (interleukin), LH - hormon luteinizujący (luteinizing hormone), MHC - główny układ zgodności tkankowej (major histocompatibility complex), MPO - mieloperoksydaza (myeloperoxidase), NK - naturalne komórki cytotoksyczne (natural killers), OxLDL - utleniona postać lipoprotein o niskiej gęstości (oxidized low-density lipoproteins), PD-1 receptor programowanej śmierci (programmed death receptor 1), PTPN22 - niereceptorowe białko fosfatazy tyrozynowej typu 2 (protein tyrosine phosphatase, non-receptor type 22), P450scc - enzym oddzielający boczny łańcuch cholesterolu (cholesterol side-chain cleavage enzyme), Tc - limfocyty T cytotoksyczne (T cytotoxic), Th - limfocyty T pomocnicze ( $T$ helper), TLR - receptory Toll-podobne (Toll-like receptors), TRAb - przeciwciała wiążące się z receptorem TSH, Treg - limfocyty $T$ regulatorowe (T regulatory cells), tTG transglutaminaza tkankowa (tissue transglutaminase), ZnT8A - przeciwciała przeciwko transporterowi cynku 8 (antibodies against the zinc transporter 8).

\section{Konflikt interesów}

Autorzy deklarują brak potencjalnych konfliktów interesów.

\section{Piśmiennictwo}

[1] Ehrlich P.: On immunity with special reference to cell life. Proc. R. Soc. Lond., 1900; 66: 424-448
[2] Steinman L.: Escape from "horror autotoxicus": Pathogenesis and treatment of autoimmune disease. Cell, 1995; 80: 7-10

[3] Dighiero G., Lymberi P., Guilbert B., Ternynck T., Avrameas S.: Natural autoantibodies constitute a substantial part of normal circulating immunoglobulins. Ann. N. Y. Acad. Sci., 1986; 475: 135145

[4] Bottazzo G.F., Florin-Christensen A., Doniach D.: Islet-cell antibodies in diabetes mellitus with autoimmune polyendocrine deficiencies. Lancet, 1974; 2: 1279-1283

[5] Wilkin T.J.: The accelerator hypothesis: Weight gain as the missing link between type I and type II diabetes. Diabetologia, 2001; 44: 914-922

[6] Wilkin T.J.: The accelerator hypothesis: A review of the evidence for insulin resistance as the basis for type I as well as type II diabetes. Int. J. Obes., 2009; 33: 716-726

[7] Zhou T., Hu Z., Yang S., Sun L., Yu Z., Wang G.: Role of adaptive and innate immunity in type 2 diabetes mellitus. J. Diabetes Res., 2018; 2018: 7457269

[8] Moura J., Madureira P., Leal E.C., Fonseca A.C., Carvalho E.: Immune aging in diabetes and its implications in wound healing. Clin. Immunol., 2019; 200: 43-54

[9] Winer D.A., Winer S., Shen L., Wadia P.P., Yantha J., Paltser G., Tsui H., Wu P., Davidson M.G., Alonso M.N. i wsp.: B cells promote insulin resistance through modulation of $T$ cells and production of pathogenic IgG antibodies. Nat. Med., 2011; 17: 610-617

[10] Winer S., Chan Y., Paltser G., Truong D., Tsui H., Bahrami J., Dorfman R., Wang Y., Zielenski J., Mastronardi F. i wsp.: Normalization of obesity-associated insulin resistance through immunotherapy. Nat. Med., 2009; 15: 921-929

[11] Cooper G.S., Bynum M.L., Somers E.C.: Recent insights in the epidemiology of autoimmune diseases: Improved prevalence estimates and understanding of clustering of diseases. J. Autoimmun., 2009; 33: 197-207

[12] Gianchecchi E., Fierabracci A.: Recent advances on microbiota involvement in the pathogenesis of autoimmunity. Int. J. Mol. Sci., 2019; 20: 283

[13] Hewagama A., Richardson B.: The genetics and epigenetics of autoimmune diseases. J. Autoimmun., 2009; 33: 3-11

[14] Romagnani S.: Immunological tolerance and autoimmunity. Intern. Emerg. Med., 2006; 1: 187-196

[15] Tomer Y.: Mechanisms of autoimmune thyroid diseases: From genetics to epigenetics. Annu. Rev. Pathol., 2014; 9: 147-156

[16] Jacobson E.M., Huber A,. Tomer Y.: The HLA gene complex in thyroid autoimmunity: From epidemiology to etiology. J. Autoimmun., 2008; 30: 58-62

[17] Burek C.L., Talor M.V.: Environmental triggers of autoimmune thyroiditis. J. Autoimmun., 2009; 33: 183-189

[18] Yoshitake T., Murakami T., Yoshitake S., Suzuma K., Dodo Y., Fujimoto M., Ito S., Tsujikawa A.: Anti-hexokinase 1 antibody as a novel serum biomarker of a subgroup of diabetic macular edema. Sci. Rep., 2019; 9: 4806

[19] Schroner Z., Lazurova I., Petrovicova J.: Autoimmune thyroid dis- 
eases in patients with diabetes mellitus. Bratisl. Lek. Listy, 2008; 109: $125-129$

[20] Cerna M.: Epigenetic regulation in etiology of type 1 diabetes mellitus. Int. J. Mol. Sci., 2019; 21: 36

[21] Phillips B.E., Garciafigueroa Y., Engman C., Trucco M., Giannoukakis N.: Tolerogenic dendritic cells and T-regulatory cells at the clinical trials crossroad for the treatment of autoimmune disease; emphasis on type 1 diabetes therapy. Front. Immunol., 2019; 10: 148

[22] Erichsen M.M., Løvås K., Skinningsrud B., Wolff A.B., Undlien D.E., Svartberg J., Fougner K.J., Berg T.J., Bollerslev J., Mella B. i wsp.: Clinical, immunological, and genetic features of autoimmune primary adrenal insufficiency: Observations from a Norwegian registry. J. Clin. Endocrinol. Metab., 2009; 94: 4882-4890

[23] Bronstad I., Wolff A.S., Løvås K., Knappskog P.M., Husebye E.S.: Genome-wide copy number variation (CNV) in patients with autoimmune Addison's disease. BMC Med. Genet., 2011; 12: 111

[24] Bjanesoy T.E., Andreassen B.K., Bratland E., Reiner A., Islam S., Husebye E.S., Bakke M.: Altered DNA methylation profile in Norwegian patients with autoimmune Addison's disease. Mol. Immunol., 2014; 59: 208-216

[25] Hellesen A., Bratland E.: The potential role for infections in the pathogenesis of autoimmune Addison's disease. Clin. Exp. Immunol., 2019; 195: 52-63

[26] Hellesen A., Edvardsen K., Breivik L., Husebye E.S., Bratland E.: The effect of types I and III interferons on adrenocortical cells and its possible implications for autoimmune Addison's disease. Clin. Exp. Immunol., 2017; 176: 351-362

[27] Bizzaro N., Antico A.: Diagnosis and classification of pernicious anemia. Autoimmun. Rev., 2014; 13: 565-568

[28] Lahner E., Gentile G., Purchiaroni F., Mora B., Simmaco M., Annibale B.: Single nucleotide polymorphisms related to vitamin B12 serum levels in autoimmune gastritis patients with or without pernicious anaemia. Dig. Liver Dis., 2015; 47: 285-290

[29] Lahner E., Annibale B.: Pernicious anemia: New insights from a gastroenterological point of view. World J. Gastroenterol., 2009; 15: 5121-5128

[30] Chou R., Bougatsos C., Blazina I., Mackey K., Grusing S., Selph S.: Screening for celiac disease: Evidence report and systematic review for the US preventive services task force. JAMA, 2017; 317: $1258-1268$

[31] Ludvigsson J.F., Bai J.C., Biagi F., Card T.R., Ciacci C., Ciclitira P.J., Green P.H., Hadjivassiliou M., Holdoway A., van Heel D.A. i wsp.: D. Diagnosis and management of adult coeliac disease: Guidelines from the British Society of Gastroenterology. Gut, 2014; 63: 1210-1228

[32] Garner C.P., Murray J.A., Ding Y.C., Tien Z., van Heel D.A., Neuhausen S.L.: Replication of celiac disease UK genome-wide association study results in a US population. Hum. Mol. Genet., 2009; 18: $4219-4225$

[33] Ohlsson B., Ekblad E., Veress B., Montgomery A., Janciauskiene S.: Antibodies against gonadotropin-releasing hormone $(\mathrm{GnRH})$ and destruction of enteric neurons in 3 patients suffering from gastrointestinal dysfunction. BMC Gastroenterol., 2010; 10: 48

[34] Betterle C., Dal Pra C., Mantero F., Zanchetta R.: Autoimmune adrenal insufficiency and autoimmune polyendocrine syndromes: Autoantibodies, autoantigens, and their applicability in diagnosis and disease prediction. Endocr. Rev., 2002; 23: 327-364

[35] Checchi S., Montanaro A., Ciuoli C., Brusco L., Pasqui L., Fioravanti C., Sestini F., Pacini F.: Prevalence of parietal cell antibodies in a large cohort of patients with autoimmune thyroiditis. Thyroid, 2010; 20: 1385-1389

[36] Kahaly G.J., Frommer L.: Polyglandular autoimmune syndromes. J. Endocrinol. Invest., 2018; 41: 91-98

[37] Nederstigt C., Uitbeijerse B.S., Janssen L.G., Corssmit E.P., de Koning E.J., Dekkers O.M.: Associated auto-immune disease in type 1 diabetes patients: A systematic review and meta-analysis. Eur. J. Endocrinol., 2019; 180: 135-144

[38] Shimura K., Miura J., Kawamoto M., Kawaguchi Y., Yamanaka H., Uchigata Y.: Genetic differences between type 1 diabetes with and without other autoimmune diseases. Diabetes Metab. Res. Rev., 2018; 34: e3023

[39] Stene L.C., Rewers M.: Immunology in the clinic review series; focus on type 1 diabetes and viruses: The enterovirus link to type 1 diabetes: Critical review of human studies. Clin. Exp Immunol., 2012; 168: 12-23

[40] Wen L., Ley R.E., Volchkov P.Y., Stranges P.B., Avanesyan L., Stonebraker A.C., Hu C., Wong F.S., Szot G.L., Bluestone J.A. i wsp.: Innate immunity and intestinal microbiota in the development of type 1 diabetes. Nature, 2008; 455: 1109-1113

[41] Sepa A., Wahlberg J., Vaarala O., Frodi A., Ludvigsson J.: Psychological stress may induce diabetes-related autoimmunity in infancy. Diabetes Care, 2005; 28: 290-295

[42] Bach J.F., Chatenoud L.: The hygiene hypothesis: An explanation for the increased frequency of insulin-dependent diabetes. Cold Spring Harb. Perspect. Med., 2012; 2: a007799

[43] Frederiksen B., Kroehl M., Lamb M.M., Seifert J., Barriga K., Eisenbarth G.S., Rewers M., Norris J.M.: Infant exposures and development of type 1 diabetes mellitus: The diabetes autoimmunity study in the young (DAISY). JAMA Pediatr., 2013; 167: 808-815

[44] Zipitis C.S., Akobeng A.K.: Vitamin D supplementation in early childhood and risk of type 1 diabetes: A systematic review and meta-analysis. Arch. Dis. Child., 2008; 93: 512-517

[45] Norris J.M., Yin X., Lamb M.M., Barriga K., Seifert J., Hoffman M., Orton H.D., Barón A.E., Clare-Salzler M., Chase H.P. i wsp.: Omega-3 polyunsaturated fatty acid intake and islet autoimmunity in children at increased risk for type 1 diabetes. JAMA, 2007; 298: $1420-1428$

[46] Hemminki K., Liu X., Försti A., Sundquist J., Sundquist K., Ji J.: Subsequent type 2 diabetes in patients with autoimmune disease. Sci. Rep., 2015; 5: 13871

[47] Toulis K., Tsekmekidou X., Potolidis E., Didangelos T., Gotzamani-Psarrakou A., Zebekakis P., Daniilidis M., Yovos J., Kotsa K.: Thyroid autoimmunity in the context of type 2 diabetes mellitus: 
Implications for vitamin D. Int. J. Endocrinol., 2015; 2015: 710363

[48] Kizilgul M., Ozcelik O., Beysel S., Akinci H., Kan S., Ucan B., Apaydin M., Cakal E.: Screening for celiac disease in poorly controlled type 2 diabetes mellitus: Worth it or not? BMC Endocr. Disord., 2017; 17: 62

[49] Cao Y.L., Zhang F.Q., Hao F.Q.: Th1/Th2 cytokine expression in diabetic retinopathy. Genet. Mol. Res., 2016; 15: 15

[50] Sathyapalan T., Atkin S.L.: Is there a role for immune and antiinflammatory therapy in type 2 diabetes? Minerva Endocrinol., 2011; 36: 147-156

[51] Bułdak Ł., Łabuzek K., Bułdak R.J., Kozłowski M., Machnik G., Liber S., Suchy D., Duława-Bułdak A., Okopień B.: Metformin affects macrophages' phenotype and improves the activity of glutathione peroxidase, superoxide dismutase, catalase and decreases malondialdehyde concentration in a partially AMPK-independent manner in LPS-stimulated human monocytes/macrophages. Pharmacol. Rep., 2014; 66: 418-429

[52] Xu X., Lin S., Chen Y., Li X., Ma S., Fu Y., Wei C., Wang C., Xu W.: The effect of metformin on the expression of GPR109A, NF-KB and IL-1 $\beta$ in peripheral blood leukocytes from patients with type 2 diabetes mellitus. Ann. Clin. Lab. Sci., 2017; 47: 556-562

[53] Herder C., Dalmas E., Böni-Schnetzler M., Donath M.Y.: The IL-1 pathway in type 2 diabetes and cardiovascular complications. Trends Endocrinol. Metab., 2015; 26: 551-563

[54] Ridker P.M., Everett B.M., Thuren T., MacFadyen J.G., Chang W.H., Ballantyne C., Fonseca F., Nicolau J., Koenig W., Anker S.D. i wsp.: Antiinflammatory therapy with canakinumab for atherosclerotic disease. N. Engl. J. Med., 2017; 377: 1119-1131

[55] McCaughtry T.M., Hogquist K.A.: Central tolerance: What have we learned from mice? Semin. Immunopathol., 2008; 30: 399-409

[56] Gianchecchi E., Delfino D.V., Fierabracci A.: NK cells in autoimmune diseases: Linking innate and adaptive immune responses. Autoimmun. Rev., 2018; 17: 142-154

[57] Goodnow C.C., Sprent J., Fazekas de St Groth B., Vinuesa C.G.: Cellular and genetic mechanisms of self tolerance and autoimmunity. Nature, 2005; 435: 590-597

[58] Fontenot J.D., Gavin M.A., Rudensky A.Y.: Foxp3 programs the development and function of $\mathrm{CD} 4^{+} \mathrm{CD} 25^{+}$regulatory T cells. Nat. Immunol., 2003; 4: 330-336

[59] Okubo Y., Torrey H., Butterworth J., Zheng H., Faustman D.L.: Treg activation defect in type 1 diabetes: Correction with TNFR2 agonism. Clin. Transl. Immunology, 2016; 5: e56

[60] Wang M., Chen F., Wang J., Zeng Z., Yang Q., Shao S.: Th17 and Treg lymphocytes in obesity and Type 2 diabetic patients. Clin. Immunol., 2018; 197: 77-85

[61] El-Shabrawy R.M., Ahmed A.M., Selim F.O., Said N.M.: Association between $\mathrm{CD}^{+}, \mathrm{CD}_{2} 5^{+}, \mathrm{FOXP} 3^{+}$regulatory T-cells and cardiovascular complications in diabetic patients type 1. Egypt. J. Immunol., 2019; 26: 129-139

[62] Abouzeid S., Sherif N.: Role of alteration in Treg/Th17 cells' balance in nephropathic patients with Type 2 diabetes mellitus. Electron. Physician., 2015; 7: 1613-1618
[63] Pelanda R., Piccirillo C.A.: Tolerance, immune regulation, and autoimmunity: Cells and cytokines that make a difference. Curr. Opin. Immunol., 2008; 20: 629-631

[64] Abdel-Moneim A., Bakery H.H., Allam G.: The potential pathogenic role of IL-17/Th17 cells in both type 1 and type 2 diabetes mellitus. Biomed. Pharmacother., 2018; 101: 287-292

[65] Qiu A.W., Liu Q.H., Wang J.L.: Blocking IL-17A alleviates diabetic retinopathy in rodents. Cell Physiol. Biochem., 2017; 41: 960-972

[66] Lavoz C., Rayego-Mateos S., Orejudo M., Opazo-Ríos L., Marchant V., Marquez-Exposito L., Tejera-Muñoz A., Navarro-González J.F., Droguett A., Ortiz A. i wsp.: Could IL-17A be a novel therapeutic target in diabetic nephropathy? J. Clin. Med., 2020; 9: 272

[67] Cortvrindt C., Speeckaert R., Moerman A., Delanghe J.R., Speeckaert M.M.: The role of interleukin-17A in the pathogenesis of kidney diseases. Pathology, 2017; 49: 247-258

[68] Gauci M.L., Boudou P., Baroudjian B., Vidal-Trecan T., Da Meda L., Madelaine-Chambrin I., Basset-Seguin N., Bagot M., Pages C., Mourah S. i wsp.: Occurrence of type 1 and type 2 diabetes in patients treated with immunotherapy (anti-PD-1 and/or anti-CTLA-4) for metastatic melanoma: A retrospective study. Cancer Immunol. Immunother., 2018; 67: 1197-1208

[69] Parenti A., Pala L., Paccosi S., Rotella C.M.: Potential role for dendritic cells in endothelial dysfunction, diabetes and cardiovascular disease. Curr. Pharm. Des., 2017; 23: 1435-1444

[70] Mráz M., Cinkajzlová A., Kloučková J., Lacinová Z., Kratochvílová H., Lipš M., Pořízka M., Kopecký P., Lindner J., Kotulák T. i wsp.: Dendritic cells in subcutaneous and epicardial adipose tissue of subjects with type 2 diabetes, obesity, and coronary artery disease. Mediators Inflamm., 2019; 2019: 5481725

[71] Marca V., Gianchecchi E., Fierabracci A.: Type 1 diabetes and its multi-factorial pathogenesis: The putative role of NK cells. Int. J. Mol. Sci., 2018; 19: 794

[72] Chiba H., Fukui A., Fuchinoue K., Funamizu A., Tanaka K., Mizunuma $\mathrm{H}$.: Expression of natural cytotoxicity receptors on and intracellular cytokine production by NK cells in women with gestational diabetes mellitus. Am. J. Reprod. Immunol., 2016; 75: 529 538

[73] Lobo T.F., Borges C.M., Mattar R., Gomes C.P., de Angelo A.G., Pendeloski K.P., Daher S.: Impaired Treg and NK cells profile in overweight women with gestational diabetes mellitus. Am. J. Reprod. Immunol., 2018; 79: e12810

[74] Tylutka A., Zembroń-Łacny A.: Starzenie się układu immunologicznego i jego konsekwencje dla zdrowia. Postępy Hig. Med. Dośw., 2020; 74: 259-270

[75] Wańkowicz-Kalińska A.: Zjawiska autoimmunizacyjne. W: Immunologia, red.: J. Gołąb, M. Jakóbisiak, W. Lasek, T. Stokłosa PWN, Warszawa 2012, 360-362

[76] Nikolov A., Tzekova M., Blazhev A.: Relationship between lipid indices, type IV collagen turnover and the development of microvascular complications in diabetic patients with arterial hypertension. Folia Med., 2019; 61: 231-239

[77] Attawia M.A., Nayak R.C.: Circulating antipericyte autoantibodies 
in diabetic retinopathy. Retina, 1999; 19: 390-400

[78] Nayak R.C., Agardh C.D., Kwok M.G., Stjernquist H., FarthingNayak P.J., Agardh E.: Circulating anti-pericyte autoantibodies are present in type 2 diabetic patients and are associated with nonproliferative retinopathy. Diabetologia, 2003; 46: 511-513

[79] Zhang L., Li Y., Payne J., Srivastava S., Fan X., Fung J., Li X., Kern T.S., Lin F.: Presence of retinal pericyte-reactive autoantibodies in diabetic retinopathy patients. Sci. Rep., 2016; 6: 20341

[80] Fredrikson G.N., Anand D.V., Hopkins D., Corder R., Alm R., Bengtsson E., Shah P.K., Lahiri A., Nilsson J.: Associations between autoantibodies against apolipoprotein B-100 peptides and vascular complications in patients with type 2 diabetes. Diabetologia, 2009; 52: 1426-1433

[81] Vavuli S., Salonurmi T., Loukovaara S., Nissinen A.E., Savolainen M.J., Liinamaa M.J.: Elevated levels of plasma IgA autoantibodies against oxidized LDL found in proliferative diabetic retinopathy but not in nonproliferative retinopathy. J. Diabetes Res., 2016; 2016: 2614153

[82] Sinha S., Saxena S., Das S., Prasad S., Bhasker S.K., Mahdi A.A., Kruzliak P.: Antimyeloperoxidase antibody is a biomarker for progression of diabetic retinopathy. J. Diabetes Complications, 2016; 30: 700-704

[83] Yoshitake S., Murakami T., Suzuma K., Yoshitake T., Uji A., Morooka S., Dodo Y., Fujimoto M., Shan Y., Fort P.E. i wsp.: Antifumarase antibody promotes the dropout of photoreceptor inner and outer segments in diabetic macular oedema. Diabetologia, 2019; 62: 504-516

[84] Türk A., Mollamehmetoğlu S., Alver A., Menteşe A., Nuhoğlu I., Erem C., Imamoğlu H.I.: The relationship between serum carbonic anhydrase I-II autoantibody levels and diabetic retinopathy in type 1 diabetes patients. Turk. J. Ophthalmol., 2017; 47: 85-88

[85] Nakaizumi A., Fukumoto M., Kida T., Suzuki H., Morishita S., Satou T., Oku H., Ikeda T., Nakamura K.: Measurement of serum and vitreous concentrations of anti-type II collagen antibody in diabetic retinopathy. Clin. Ophthalmol., 2015; 9: 543-547

[86] Lopes-Virella M.F., Hunt K.J., Baker N.L., Virella G., VADT Group of Investigators: High levels of AGE-LDL, and of IgG antibodies reacting with MDA-lysine epitopes expressed by oxLDL and MDALDL in circulating immune complexes predict macroalbuminuria in patients with type 2 diabetes. J. Diabetes Complications, 2016; 30: 693-699

[87] Virella G., Carter R.E., Saad A., Crosswell E.G., Game B.A., DCCT/EDIC Study Group, Lopes-Virella M.F.: Distribution of IgM and $\lg G$ antibodies to oxidized LDL in immune complexes isolated from patients with type 1 diabetes and its relationship with nephropathy. Clin. Immunol., 2008; 127: 394-400

[88] Zimering M.B., Zhang J.H., Guarino P.D., Emanuele N., McCullough P.A., Fried L.F., Investigators for the VA NEPHRON-D: Endothelial cell autoantibodies in predicting declining renal function, end-stage renal disease, or death in adult type 2 diabetic nephropathy. Front. Endocrinol., 2014; 5: 128

[89] Ge S., Xie J., Zheng L., Yang L., Zhu H., Cheng X., Shen F.:
Associations of serum anti-ganglioside antibodies and inflammatory markers in diabetic peripheral neuropathy. Diabetes Res. Clin. Pract., 2016; 115: 68-75

[90] Menichella D.M., Jayaraj N.D., Wilson H.M., Ren D., Flood K., Wang X.Q., Shum A., Miller R.J., Paller A.S.: Ganglioside GM3 synthase depletion reverses neuropathic pain and small fiber neuropathy in diet-induced diabetic mice. Mol. Pain, 2016; 12 : 1744806916666284

[91] Ejskjaer N., Arif S., Dodds W., Zanone M.M., Vergani D., Watkins P.J., Peakman M.: Prevalence of autoantibodies to autonomic nervous tissue structures in type 1 diabetes mellitus. Diabet. Med.; 1999; 16: 544-549

[92] Gottumukkala R.V., Lv H., Cornivelli L., Wagers A.J., Kwong R.Y., Bronson R., Stewart G.C., Schulze P.C., Chutkow W., Wolpert H.A. i wsp.: Myocardial infarction triggers chronic cardiac autoimmunity in type 1 diabetes. Sci. Transl. Med., 2012; 4: 138ra80

[93] Hoffman W.H., Sharma M., Cihakova D., Talor M.V., Rose N.R., Mohanakumar T., Passmore G.G.: Cardiac antibody production to self-antigens in children and adolescents during and following the correction of severe diabetic ketoacidosis. Autoimmunity, 2016; 49: 188-196

[94] Roth B., Berntorp K., Ohlsson B.: The expression of serum antibodies against gonadotropin-releasing hormone $(\mathrm{GnRH} 1)$, progonadoliberin-2, luteinizing hormone (LH), and related receptors in patients with gastrointestinal dysfunction or diabetes mellitus. Drug Target Insights, 2014; 8: 45-50

[95] Rizzo P., Pitocco D., Zaccardi F., Di Stasio E., Strollo R., Rizzi A., Scavone G., Costantini F., Galli M., Tinelli G. i wsp.: Autoantibodies to post-translationally modified type I and II collagen in Charcot neuroarthropathy in subjects with type 2 diabetes mellitus. Diabetes Metab. Res. Rev., 2017; 33: e2839

[96] Xiao X., Ma B., Dong B., Zhao P., Tai N., Chen L., Wong F.S., Wen L.: Cellular and humoral immune responses in the early stages of diabetic nephropathy in NOD mice. J. Autoimmun., 2009; 32: $85-93$

[97] Nicoloff G., Blazhev A., Petrova C., Christova P.: Circulating immune complexes among diabetic children. Clin. Dev. Immunol., 2004; 11: 61-66

[98] Li T., Yu Z., Qu Z., Zhang N., Crew R., Jiang Y.: Decreased number of $\mathrm{CD} 19^{+} \mathrm{CD} 24^{\mathrm{hi}} \mathrm{CD} 38^{\mathrm{hi}}$ regulatory $\mathrm{B}$ cells in diabetic nephropathy. Mol. Immunol., 2019; 112: 233-239

[99] Zhang N., Tai J., Qu Z., Zhang Z., Zhao S., He J., Zhang S., Jiang Y.: Increased $\mathrm{CD} 4^{+} \mathrm{CXCR} 5^{+} \mathrm{T}$ follicular helper cells in diabetic nephropathy. Autoimmunity, 2016; 49: 405-413

[100] Cameron N.E., Eaton S.E., Cotter M.A., Tesfaye S.: Vascular factors and metabolic interactions in the pathogenesis of diabetic neuropathy. Diabetologia, 2001; 44: 1973-1988

[101] Elzinga S., Murdock B.J., Guo K., Hayes J.M., Tabbey M.A., Hur J., Feldman E.L.: Toll-like receptors and inflammation in metabolic neuropathy; a role in early versus late disease? Exp. Neurol., 2019; 320: 112967

[102] Janahi N.M., Santos D., Blyth C., Bakhiet M., Ellis M.: Diabetic 
peripheral neuropathy, is it an autoimmune disease? Immunol. Lett., 2015;168: 73-79

[103] Zanone M.M., Raviolo A., Coppo E., Trento M., Trevisan M., Cavallo F., Favaro E., Passera P., Porta M., Camussi G.: Association of autoimmunity to autonomic nervous structures with nerve function in patients with type 1 diabetes: A 16-year prospective study. Diabetes Care, 2014; 37: 1108-1115

[104] Schnell O., Schwarz A., Muhr-Becker D., Standl E.: Autoantibodies against autonomic nervous tissues in type 2 diabetes mellitus: No association with cardiac autonomic dysfunction. Exp. Clin. Endocrinol. Diabetes, 2000; 108: 181-186

[105] Łukawska-Tatarczuk M., Mrozikiewicz-Rakowska B., Franek E., Czupryniak L.: Podłoże molekularne niewydolności serca w cukrzycy - nowe możliwości terapeutyczne. Postępy Hig. Med. Dośw., 2020; 74: 452-463

[106] Lv H., Havari E., Pinto S., Gottumukkala R.V., Cornivelli L., Raddassi K., Matsui T., Rosenzweig A., Bronson R.T., Smith R. i wsp.: Impaired thymic tolerance to a-myosin directs autoimmunity to the heart in mice and humans. J. Clin. Invest., 2011; 121: 1561-1573
[107] Sousa G.R., Pober D., Galderisi A., Lv H., Yu L., Pereira A.C., Doria A., Kosiborod M., Lipes M.A.: Glycemic control, cardiac autoimmunity, and long-term risk of cardiovascular disease in type 1 diabetes mellitus. Circulation, 2019; 139: 730-743

[108] Tomaszewska A., Mrozikiewicz-Rakowska B., Czupryniak L.: Diabetic enteropathy - still undefeated? Clin. Diabetology, 2017; 6: 105-110

[109] D’Addio F., La Rosa S., Maestroni A., Jung P., Orsenigo E., Ben Nasr M., Tezza S., Bassi R., Finzi G., Marando A. i wsp.: Circulating IGF-I and IGFBP3 levels control human colonic stem cell function and are disrupted in diabetic enteropathy. Cell Stem Cell, 2015; 17: 486-498

[110] Bereket A., Lang C.H., Wilson T.A.: Alterations in the growth hormone-insulin-like growth factor axis in insulin dependent diabetes mellitus. Horm. Metab. Res., 1999; 31: 172-181 